\section{Leonard Darwin Scholarship of the Eugenics Society}

ThE Eugenics Society has established a second Leonard Darwin scholarship, which is to be devoted to the investigation of racial crossing. The first holder is J. C. Trevor, a graduate of Oxford in anthropology, who has spent the last two years studying mixtures of negro and white stocks in the United States, with the aid of a Commonwealth fellowship. $\mathrm{He}$ has collected ethnological material in the Virgin Islands and in East Africa, and with Dr. Dudley Buxton has made an investigation of English medieval skulls. He has also a collection of biometric material on West African and American negro crania. Mr. Trevor will devote a year to a survey of the literature on the subject of inter-racial crossing.

\section{Another New Star in Aquila}

Tre Swedish observer, Mr. Nils Tamm, who discovered a nova of magnitude 8 in Aquila last month, has now detected another of these bodies in the same constellation. The latest nova was announced on October 20 as having been found on a plate taken on October 7, when the magnitude is stated to have been $7 \cdot 0$. Dr. W. H. Steavenson, who gives the position of the nova for 1936.0 as R.A. $19^{\text {h }} 23^{\text {m }} 28 \cdot 16^{\text {s }}$, North Decl. $7^{\circ} 28^{\prime} 32 \cdot 5^{\prime \prime}$, finds the magnitude to be about $8 \cdot 0$, with little fading between October 21 and 25. He reports the colour as being fiery red. In the spectrum the red line of hydrogen $(\mathrm{H} \alpha)$ is very bright and prominent, and contributes a large proportion of the total visual light of the nova. Tamm's earlier nova is still of about the eighth magnitude, after undergoing some marked fluctuations since its discovery. The two novæ can just be seen simultaneously in a good prism binocular, being only a little more than six degrees apart.

\section{The Night Sky in November}

AT the beginning of the month, the duration of night (defined as the interval from sunset to the following sunrise) is 14.4 hours, and at the end of the month 15.9 hours in the latitude of London. The moon is new on November $14^{\mathrm{d}} 4 \cdot 7^{\mathrm{h}}$ and full on November $28^{\mathrm{d}} 16 \cdot 2^{\mathrm{h}}$ U.T. Occultations of stars brighter than magnitude 5 occur on November 28-29, when $x$ Tauri reappears at $17^{\mathrm{h}} 30 \cdot 6^{\mathrm{m}}$ and $\tau$ Tauri disappears at $23^{\mathrm{h}} 48 \cdot 4^{\mathrm{m}}$ and reappears at $1^{\mathrm{h}} 0 \cdot 2^{\mathrm{m}}$. The planet Venus sets this month in the early evening, and at sunset is low in the south-west. Jupiter is in the same region of the sky, and on the evening of November 12 will be found about $2^{\circ}$ above Venus. The near approach of these two bright objects (actual conjunction takes place on November $13^{\mathrm{d}} 12^{\mathrm{h}}$ ) will be well worth looking for at nightfall on November 12 and following with telescopic aid about midday on November 13. Mars is a morning star of magnitude about $+1 \cdot 8$. Saturn is above the horizon during the first part of the night; on November 15 it sets just before $1^{\text {h }}$. Watch may be kept on November 15-16 for a possible display of the Leonid meteors. This shower, the radiant point of which is at R.A. $10^{\mathrm{h}} 0^{\mathrm{m}}$, Dec. $+22^{\circ}$, is generally visible every November, but at epochs of every $\mathbf{3 3}$ years it yields, with some exceptions, an unusually brilliant display. The last great shower was due in 1932, but in Great Britain it failed to come up to expectations, though at one station in the United States as many as $\mathbf{2 4 0}$ meteors were observed in an hour. November 19-20 is the date of maximum of the Andromedids, a shower associated with the lost comet of Biela; the radiant of the shower is not far from the star $\gamma$ Andromedæ. (Near $v$ Andromedæ may be seen, with the naked eye, a tiny, faint hazy patch which is the Andromeda nebula, distant 870,000 light years.) The light variations of Algol ( $\beta$ Persei) can be observed at about the following times: November $8^{d} 2^{\mathrm{h}}, 10^{\mathrm{d}} 23^{\mathrm{h}}$, $13^{\mathrm{d}} 19^{\mathrm{h}}, 28^{\mathrm{d}} 4^{\mathrm{h}}$ and December $1^{\mathrm{d}} 0^{\mathrm{h}}$. In midNovember at about $22^{\mathrm{h}}$, the constellations Cassiopeia, Perseus, Andromeda, Aries and Cetus are on or near the meridian, but the eastern half of the sky, rich in first magnitude stars and led by the Pleiades, will probably claim the observer's attention.

\section{Announcements}

TuE Right Hon. Lord Rutherford will deliver the twelfth annual Norman Lockyer Lecture of the British Science Guild at the Goldsmiths' Hall, Foster Lane, London, E.C.2, on November 12 at 4.30 p.m. The title of Lord Rutherford's lecture will be "Science in Development". This is the last occasion upon which the Norman Lockyer Lecture will be arranged by the British Science Guild as an independent body. In future the lecture will be carried on under the auspices of the British Association. Tickets for Lord Rutherford's lecture are obtainable, free of charge, on application to the Secretary, British Science Guild, 535-7 Abbey House, Victoria Street, London, S.W.1.

Sir Thomas Holland will deliver the Huxley Lecture at the Imperial College of Science and Technology on May 4, 1937, at 5.30 p.m. The subject of Sir Thomas's lecture will be "The Permanence of Oceanic Depressions and Continental Elevations".

Prof. S. ChAPMAN, chief professor of mathematics in the Imperial College of Science, has been elected a member of the Kaiserlich Deutsche Akademie der Naturforscher, Halle, in recognition of his researches in terrestrial magnetism.

The Chadwick Gold Medal and Prize for excellence in municipal engineering and hygiene was presented to Mr. E. A. Drew, of University College, London, on October 27.

AT the annual statutory meeting of the Royal Society of Edinburgh held on October 26, the following Council was elected: President: Prof. D'Arcy Wentworth Thompson; Vice-Presidents : Principal O. Charnock Bradley; Prof. P. T. Herring; the Marquis of Linlithgow ; Prof. E. B. Bailey; Prof. F. A. E. Crew ; and Lieut. Col. A. G. M'Kendrick; General Secretary: Prof. James P. Kendall ; Secretaries to Ordinary Meetings: Dr. A. C. Aitken and Dr. C. H. O'Donoghue; Treasurer: Dr. James 
Watt ; Curator of Library and Museum : Dr. Leonard Dobbin; Councillors: Principal J. C. Smail ; Sir Harold J. Stiles; Prof. J. Walton; Prof. Edwin Bramwell ; Prof. T. H. Bryce; Prof. I. de Burgh Daly ; Mr. J. A. Inglis ; Prof. A. D. Peacock; Dr. J. E. Mackenzie ; Prof. Sydney Smith; Prof. Ralph Stockman; and Dr. E. Maclagan Wedderburn.

A Bronze bust of Dr. Emile Roux was recently unveiled at Angoulême, where addresses were delivered by Prof. Marchoux, representing the Paris Academy of Medicine, and Dr. Louis Martin, Roux's successor at the Pasteur Institute.

A Pan-Russian scientific institute for the study of the bacteriophage has been erected at Tiflis, and will be opened next year under the direction of Prof. F. d'Hérelle.

AT the ninety-fourth Congress of the Society of German Men of Science and Physicians, recently held at Dresden, a German Society of Hygiene was founded under the presidency of Prof. Hans Reiter, president of the Health Office of the Reich.

Tre Argentine Government has formed a national committee of intellectual co-operation with the object of promoting intellectual co-operation with different countries in science, literature, art, education, etc. The committee will enter into relations with the International Institute of Intellectual Co-operation in Paris and the International Office of Fducation at Geneva.

Messrs. James Treciaskis and Son, of 66 Great Russell Street, London, W.C.1, in their Caxton Head Catalogue, No. 1023, are offering for sale some interesting Newton papers. This includes John Flamstead's "Historia Cœlestis", a collection relating to the "Historia Cœlestis" published by Newton and Halley without the consent of the author; a letter by Newton to Sir Richard Onslow ; Newton's signature on an oblong vellum document; a letter from Menschikoff to Newton concerning the former's fellowship of the Royal Society, together with three autographed drafts of Newton's reply; a note on the calculus by Newton; several letters on the calculus; and a letter to Newton from John $T$. Desaguliers, inventor of the planetarium.

The Imperial Council of Agxicultural Research, Simla, announces that there is a surplus stock of certain agricultural and veterinary publications for free disposal (packing and carriage to be paid by the indentor). The following are listed: Handbooks of Commercial Products (17 different volumes); Catalogue of Indian Insects (parts 1-22, part 11 excepted) ; Proceedings of the Board of Agriculture in India (1906-29-series incomplete). The number of copies available is limited, but in the case of the Commercial Handbooks is quite considerable. Application for any of these publications should be made to the Manager of Publications, Civil Iines, Delhi, on or before November 30 .
Erratum. In Nature of October 3, p. 589, in the letter entitled "A New Strigeid Parasite of the Rare Genus Cyathocotyle", for "Cyathocotyle calvusi" read "Cyathocotyle calvi".

Applications are invited for the following appoint ments, on or before the dates mentioned:

An assistant engineer in the Roads Department of the Ministry of 'Transport-The Establishment Officer, Ministry of Transport, Whitehall Gardens, London, S.W.1 (October 31).

An assistant (Grade II) (physics or engineering) in the Signals Experimental Establishment, Woolwich Common, S.F.18-The Superintendent (November 2).

An assistant lecturer in mechanical engineering, and a workshop instructor in Coventry Technical College-The Director of Fducation, Council House, Coventry (November 6).

An assistant physicist in the Radiotherapy Depart. ment of the Middlesex Hospital Medical School. W.I - The Dean (November 9).

AN assistant (man) in the Technical Education Branch and a woman organizer of instruction in domestic subjects in the Education Department of the West Riding of Yorkshire-The Edunation Officer, County Hall, Wakefield (November 9).

A University reader in mechanical engineering in King's College, London-The Academic Registrar, University of London, W.C.1 (November 10).

An Imperial mycologist at the Imperial Institute of Agricultural Research, Pusa, Bihar, India-The High Commissioner for India, General Department, India House, Aldwych, London, W.C.2 (November 10).

A metallurgical inspector in the Indian Stores Department-The High Commissioner for India. General Department, India House, Aldwych, London, W.C.2 (November 13).

A principal of Twickenham 'Technical Institute-.. H. M. Walton, 10 Great George Street, Westminster. S.W.1 (November 14).

A technical officer (ref. A. 263) and assistants (Grade III) at the Royal Aircraft Establishment. South Farnborough, Hants-The Chief Superintendent (November 14).

A lecturer in experimental zoology in the University. of Edinburgh-The Secretary (November 21).

A St. Mungo professor of pathology in the University of Glasgow-The Secretary to the University Court (November 26).

A principal of the Farm School and Officer-in Charge of the School Farm and Experimental Station in the Department of Agriculture, Peradeniya, Ceylon --The Director of Recruitment (Colonial Service), 2 Richmond Terrace, Whitehall, S.W.1 (November 30).

An assistant research chemist at the British Drug Houses, Ltd., Graham Street, City Road, N.1-The Secretary.

An executive engineer in the Public Works Department of the Government of Sierra Leone-The Crown Agents for the Colonies, 4 Millbank, London, S.W.1 (quote $M / 4572$ ).

A reader in bacteriology in the Department of Patholcgy, University of Oxford-The Professor of Pathology. 